\title{
Hegemony Masculinity in Online Media News Coverage
}

\author{
$1^{\mathrm{st} *}$ Puti Nadhira \\ Dept. of Communication Science \\ Universitas Indonesia \\ Jakarta, Indonesia \\ nadhiraputi@gmail.com
}

\author{
$2^{\text {nd }}$ Fitria Angeliqa \\ Dept. of Communication Science \\ Universitas Indonesia \\ Jakarta, Indonesia \\ ivyangeliaca@yahoo.com
}

\begin{abstract}
The role of the mass media in the dissemination of information has become very important in this digital era, including news about sports competitions. However, sport still has gender issues which then distinguish the presence of male athletes and female athletes. This problem also occurs regarding to the coverage of athletes in the mass media. Framing by the media can influence readers about their views on certain athletes. Thus, the researcher wants to do a content analysis of male and female athletes' news in online media to find out whether the media encourages gender issues, namely hegemony of masculinity. In addition, researchers also want to find out whether there is a difference in the amount of news between male athletes and female athletes. Using quantitative methods, researchers analyzed a sample of 62 news of Indonesian male and female athletes who won the Indonesia Masters 2020 gold medal on the Indonesian news portal sites. The results showed that even though the gender description categories tended to be the same, 14 of the 26 gender-specific descriptors used indicated that there was still a tendency of the hegemony of masculinity in the media.
\end{abstract}

Keywords—component, formatting, style, styling, insert

\section{INTRODUCTION}

Mass media has a very important role in the dissemination of information in this digital era. Through any kind of platform of media, people can access any kind of news or coverage reported by said media. Every aspects of life have become subject to be informed to the masses, competitions or sorts are some of them. According to Riffe et. al., every individual must be exposed to the mass media through what they hear, see and read in everyday life. [1]

Competitions or any kind of sport tournaments have become an interesting issue and news material for mass media. Indonesia itself has held a lot of sports competitions both from national to international levels with various sports that are contested. Aside from the competition itself, the athletes who took part in the competition were always in the public spotlight and attracted the attention of the media to be reported.

The mass media has produced content about sports through print, radio, television and the internet. Although the number of female participants participating in sports has increased, some studies by Kane and Duncan have shown that there are generally differences in the amount of media coverage between male and female athletes. [2]
Many researches that analyze gender in sport media coverage show men get exposed more than women in any level of sports. [3] [4]

Some researches reveal that the majority of media coverage in the field of sports is more dominant in presenting news that has masculinity values such as reporting about sports conducted by male athletes and reporting on male athletes themselves compared to reporting on female athletes. [1]

Another study conducted by Pedersen (2002) revealed that there is a dominant aspect of photography in male athletes in newspapers than in female athlete photography in which male athlete photos are published more in newspapers, positioned in strategic columns and more color photo. [5]

In addition, a study conducted by Malik (2016) revealed the same thing, namely the dominance of media coverage in male athletes where there were more news articles about male athletes, and a large number of coverage of male athlete photographs. [6]

While the results of research by Kian, Mondello, and Vincent (2009) on the analysis of the dominance of the news on male and female athletes in two media, CBS SportLine and ESPN Internet Network, showed that CBS SportLine exposes more about male athletes and ESPN Internet exposes more news about female athletes.

According to Hardin, Lynn, \& Walsdorf (2005) like mass media, sports are also seen as "a powerful hegemonic institution". [7] Hargreaves in (Hardin et. al., 2005) says that through sports, individuals are socialized to learn "genderappropriate" behavior. Betancourt (in Hardin, 2005) mentions that boys learn about "teamwork" and "achievement-oriented" behavior through sports teams, while girls learn about cultural rules for "femininity". [7]

Gender differences mean the framing of social differences that have been constructed between men and women, as naturally different physical things. [7]

Therefore, the researcher would like to do a study to find out whether mass media, especially online media encourage hegemony of masculinity or not in reporting male and female athletes through content analysis in Indonesia.

Connell (in Schippers, 2007) defines hegemonic masculinity as a configuration of gender practices that has been understood as an answer to the problem of the adoption of patriarchal practices, which guarantees the position of male 
domination and female subordination. [8] Hegemonic masculinity is also described as a position in gender relations, practices in which men and women participate in these positions, and the effects of these practices on physical experience, personality, and culture.

According to Schippers (2007), Connell's definition means that masculinity has three components including: 1) social location, where individuals regardless of their gender, can move through these practices; 2) a set of practices and characteristics that are understood as "masculine"; 3) When these practices have penetrated deeply, especially for men (but it can also be women), they will influence social and cultural effects. [8]

\section{RRESEARCH METHOD}

By using a positivist paradigm, the research approach used in this study is quantitative research. According to Neuman (2014), quantitative research is a study that departs from the researcher's hypothesis in the form of a clear variable concept. Calculations in research are made systematically before data collection with existing standards.

While the method used in this study is the content analysis method. Content analysis which is a study of human communication, has become a research method commonly applied to "media coverage of women 's sports" (Babbie, 2008; Malik, 2016).

According to Neuman (2014) content analysis is a technique for examining content or information and symbols contained in written documents or other communication media, such as photographs, films, song lyrics, or advertisements. Content analysis allows researchers to find and document specific features of large amounts of material that may not be noticed. [9]

Content analysis is performed on the number or frequency of news and the variety of content or news content between male athletes and female athletes. The news content is then classified according to indicators in 10 news categories based on Kian et al. (2009), namely physical appearance-attire, physical appearance-sport lingo, athletic processes, athletic weakness/ limitations, skill-level accomplishment-positive, skill-level failure-negative, family role / personal relationship, psychological / emotional strengths, psychological / emotional weakness and humor.

In this study, the object of study was the news coverage of male and female athletes at the Indonesia Masters 2020 event, from January 14 to January 19, 2020 on the okezone.com and tribunnews.com news portals, the two highest rank news portal in Indonesia. This study uses a probability sampling technique which then obtained a sample of 62 news from a population of 151 news.

News that will be examined are grouped first and then the coding process is carried out by the encoder. There are two coding schemes in content analysis namely codebook and coding form. Codebook is a book created by researchers to explain the operationalization of variables clearly. Coding form is a form that consists of information in the form of a checklist sheet on the codebook. The coding form explains what is meant by the codebook. After that testing is done directly in the field through the encoder so that it can find out whether the code is consistent and perceive the actual data.

\section{RESULT AND DISCUSSION}

Based on the population, there are a number of three male athletes and two female athletes who won gold medals at the Indonesia Masters 2020. Then in sampling, each news sample is grouped into two news topics by sex, namely men's articles and women's articles. Men's articles are articles that have a topic on the discussion of male athletes and women's articles are articles that have a topic on the subject of female athletes.

From a total of 62 news samples, there are 38 articles that cover male athletes and 24 articles that cover female athletes, so that it can be concluded that the articles that discuss the news of male athletes are more numerous than female athletes. This is in accordance with the number of male gold medalist athletes more than female athletes where the total number of male athletes who won the gold medal amounted to 3 people and female athletes numbered 2 people.

In proportion analysis, a total of three male athletes from a total of five athletes make up a proportion of $60 \%$ of the population and a total of two female athletes from a total of five athletes have a proportion of $40 \%$ of the population. However, the three male athletes were reported in 38 articles from a total of 62 news articles, so that the proportion of the total number of male athletes was $61.3 \%$.

While the two female athletes were reported in only 24 articles from a total of 62 news articles so that the proportion of female athlete coverage was $38.7 \%$. So it can be said that the number of coverage of male and female athletes is less proportional compared to the number of male and female athletes who won the Indonesia Masters 2020 gold medal. Proportional conditions can occur if the number of news articles covering female athletes is $40 \%$ or equal to 25 news articles.

Based on the analysis, the news coverage of athletes on the news portal Tribunnews.com and Okezone.com shows the proportion of the same number of reports between male athletes and female athletes. In the Tribunnews.com portal, the proportion of female athlete news articles is $42 \%$ and the proportion of male athlete news articles is $58 \%$. Whereas in the Okezone.com portal, the proportion of female athlete news articles is $35 \%$ and the proportion of male news articles is $64 \%$.

Between the two of online news portals, both have roughly the same proportion in covering the news of male and female athletes. So, it can be concluded that there is no difference in the framing of the news of the two types of online media in reporting about athletes who excel. Between Tribunnews.com and Okezone.com, both still have a smaller proportion of female athlete reporting than the number of female athletes who won the Indonesia Masters 2020 gold medal.

Content article seeks to describe the tendency of news content divided into 10 assessment categories which can be broadly grouped into four major groups, namely factual information related to athletics and non-athletics and personal information related to athletics and not athletics. 


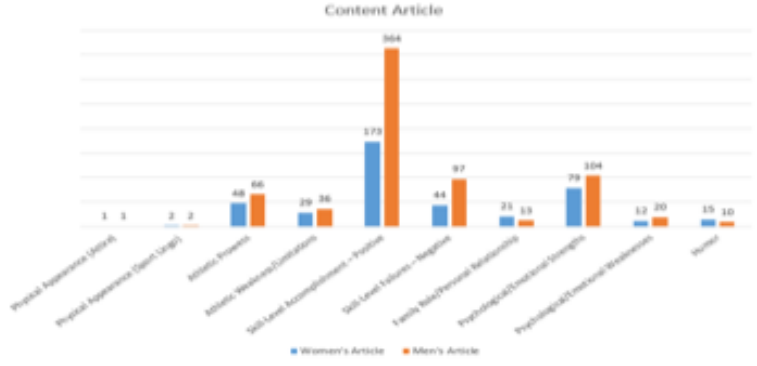

Fig. 1. Results Description of Content Article, source: processed by the researcher

The graph above shows that in men's articles and women's articles there is a tendency for women to report articles on the same five topics, namely Skill Level Accomplishment (Positive), Psychological / Emotional Strength, Skill Level Failures (Negative), Athletic Prowess, and Athletic Weakness / Limitations. The five topics show athletic information more athletes. While personal topics such as Family Role / Personal Relationship are mostly reported in women's articles. The large number of mentions indicates that it is not only one topic that is discussed in one story.

Content Photograph is used to describe what activities are displayed from the photos used in the article by calculating how many types of photos are based on "gender-specific". By analyzing the photographic content it can be seen the tendency of the intent of the image used in the article. In one picture an article can have more than one category.

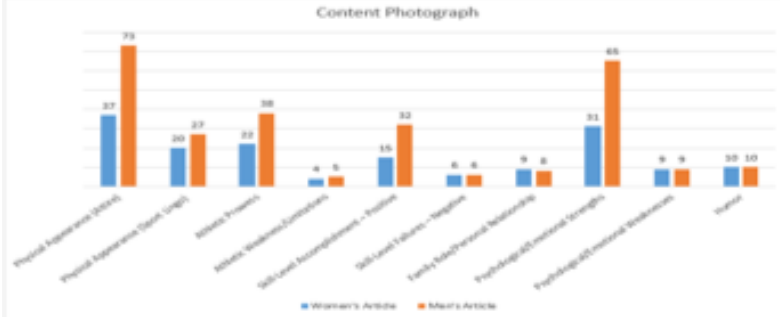

Fig. 2. . Result Description of Content Photograph, source: Processe by the researcher

The graph above shows that in men's articles and women's articles there is a tendency for women to report photos on the same five topics, namely Physical Appearance (Attire), Psychological / Emotional Strength, Physical Appearance (Sport Lingo), Athletic Prowess, and Skill Level Accomplishment (Positive).

Data processing in this study uses the $\mathrm{T}$ Test statistical technique. According to Eriyanto (2011), T Test Technique is an analysis technique that seeks to test the differences between two samples with interval or ratio scale. It is said to have a significant difference if the t-test results $<0.05$. While it is said to have no significant difference if the results of $t$-test $>0.05$. Here are the results of the analysis:

TABLE I. T-TEST TEST RESUlTS. SOURCE: PROCESSED BY THE RESEARCHER

\begin{tabular}{|l|c|}
\hline \multicolumn{1}{|c|}{ Variable } & t-test results \\
\hline Gender Article : Male athletes & .073 \\
\hline Gender Article : Female athletes & .294 \\
\hline Gender Photograph : Male athletes & .004 \\
\hline Gender Photograph : Female athletes & .808 \\
\hline
\end{tabular}

\begin{tabular}{|c|c|}
\hline $\begin{array}{l}\text { Gender Photograph : Male \& Female } \\
\text { athletes }\end{array}$ & .000 \\
\hline Gender Photograph : Not both & .010 \\
\hline $\begin{array}{l}\text { Content Article : Physical Appearance } \\
\text { (attire) }\end{array}$ & .010 \\
\hline $\begin{array}{l}\text { Content Article : Physical Appearance } \\
\text { (sport lingo) }\end{array}$ & .010 \\
\hline Content Article : Athletic Prowess & .404 \\
\hline $\begin{array}{l}\text { Content Article : Athletic } \\
\text { Limitations/Weaknesses }\end{array}$ & .027 \\
\hline $\begin{array}{l}\text { Content Article : Skill- Level } \\
\text { Accomplishment (Positive) }\end{array}$ & .200 \\
\hline $\begin{array}{l}\text { Content Article : Skill- Level Failures } \\
\text { (Negative) }\end{array}$ & 615 \\
\hline $\begin{array}{l}\text { Content Article : Family Role/Personal } \\
\text { Relationship }\end{array}$ & .000 \\
\hline $\begin{array}{l}\text { Content Article : } \\
\text { Psychological/Emotional Strengths }\end{array}$ & .586 \\
\hline $\begin{array}{l}\text { Content Article : } \\
\text { Psychological/Emotional Weaknesses }\end{array}$ & .287 \\
\hline Content Article : Humor & .001 \\
\hline $\begin{array}{l}\text { Content Photograph : Physical } \\
\text { Appearance (attire) }\end{array}$ & .010 \\
\hline $\begin{array}{l}\text { Content Photograph: Physical } \\
\text { Appearance (sport lingo). }\end{array}$ & .594 \\
\hline Content Photograph : Athletic Prowess & .385 \\
\hline $\begin{array}{l}\text { Content Photograph : Athletic } \\
\text { Limitations/Weaknesses }\end{array}$ & .036 \\
\hline $\begin{array}{l}\text { Content Photograph : Skill-Level } \\
\text { Accomplishment (Positive) }\end{array}$ & .843 \\
\hline $\begin{array}{l}\text { Content Photograph: Skill-Level Failures } \\
\text { (Negative) }\end{array}$ & .010 \\
\hline $\begin{array}{l}\text { Content Photograph : Family } \\
\text { Role/Personal Relationship }\end{array}$ & .005 \\
\hline $\begin{array}{l}\text { Content Photograph : } \\
\text { Psychological/Emotional Strengths }\end{array}$ & .653 \\
\hline $\begin{array}{l}\text { Content Photograph : } \\
\text { Psychological/Emotional Weaknesses }\end{array}$ & .010 \\
\hline Content Photograph: Humor & .010 \\
\hline
\end{tabular}

\section{CONCLUSION}

This study aims to determine the difference between the number of male athletes reporting and the number of female athletes reporting at the Indonesia Masters 2020. In addition, it is also to find out the gender-specific descriptor differences used in the male and female athletes' coverage at the Indonesia Masters 2020, and to find out whether the news of male and female athletes in the media encourages hegemony of masculinity.

In the men's and women's news article content, there are five gender-specific descriptors mostly used, namely Skill Level Accomplishment (Positive), Psychological / Emotional Strength, Skill Level Failures (Negative), Athletic Prowess, and Athletic Weakness / Limitations. While the image content of men and women mostly used are Physical Appearance (Attire), Psychological / Emotional Strength, Physical Appearance (Sport Lingo), Athletic Prowess, and Skill Level Accomplishment (Positive)

Out of the 26 categories of statements given, there were 12 categories of statements that showed that there were no significant differences between male's and female's news. While the following 14 categories show that there are significant differences, namely:

- Gender photograph: male athletes

- Gender photograph: both male and female athletes 
- Gender photograph: not both

- Content article: physical appearance (attire)

- Content article: physical appearance (sport lingo)

- Content article: athletic weakness/limitations

- Content article: family role/personal relationship

- Content article: humor

- Content photograph: physical appearance (attire)

- Content photograph: athletic weakness/limitations

- Content photograph: skill-level failures (negative)

- Content photograph: family role/personal relationship

- Content photograph: psychological/emotional weaknesses

- Content photograph: humor

The t-test results showed that there were 14 genderspecific descriptors that had a significant difference between men's news and women's news. So it can be concluded that the media encourages a hegemony of masculinity in the coverage of male and female athletes winning gold medals in Indonesia Masters 2020

Some athletes only get very minimal exposure, even some athletes are only reported once by a news site. This certainly does not reflect balance and fairness for athletes who have both struggled to make the nation proud. The athlete should be able to report more evenly and is intended to arouse enthusiasm and inspire the community rather than mere sensation.

The results of the study which showed that there were no significant differences in gender-specific descriptors for both male and female athletes, but there were t-test results indicating that there was an indication of hegemonic masculinity in the news could be further investigated.
In addition, given the limited time and effort, this study took samples only from the top two online news portals. Further research on other sports competitions or other media such as print and electronic media is needed as a comparison to find out whether there is a gender bias in the reporting of male or female athletes.

\section{REFERENCES}

[1] P. M. Pedersen, "EXAMINING EQUITY IN NEWSPAPER PHOTOGRAPHS," Int. Rev. Sociol. Sport, vol. 6902, pp. 303-318, 2002, doi: 10.1177/1012690202037004895.

[2] E. (Ted) M. Kian, M. Mondello, and J. Vincent, "ESPN - The Women 's Sports Network? A Content Analysis of Internet Coverage of March Madness," J. Broadcast. Electron. Media, no. November 2014, pp. 37-41, 2009, doi: 10.1080/08838150903102519.

[3] J. Vincent, C. Imwold, V. Masemann, J. T. Johnson, and J. T. Johnson, “A Comparison od Selected 'Serious' and 'Popular' British, Canadian, and United States Newspaper Coverage of Female and Male Athletes Competing in the Centennial Olympic Games," Int. Rev. Sociol. Sport, 2002, doi: 10.1177/101269020203700312.

[4] S. T. Eastman and A. C. Billings, "Sportscasting and Sports Reporting: The Power of Gender Bias," J. Sport Soc. Issues, vol. 24, no. 2, pp. 192-213, 2000 .

[5] K. S. Miloch and P. M. Pedersen, "The Current State of Women Print Journalists: An Analysis of the Status and Careers of Females in Newspapers Sports Departments," Public Organ. Rev. A Glob. J., vol. 232, pp. 219-232, 2005.

[6] M. R. Malik, "A CONTENT ANALYSIS OF GENDER-SPECIFIC MEDIA COVERAGE OF SPORT: NCAA ATHLETIC DEPARTMENT HOME WEBPAGES,” University of Nevada, 2016.

[7] M. Hardin, S. Lynn, and K. Walsdorf, "Challenge and Conformity on 'Contested Terrain': Images of Women in Four Women's Sport/Fitness Magazines," Sex Roles, vol. 53, no. July, 2005, doi: 10.1007/s11199-005-4285-6.

[8] M. Schippers, "Recovering the Feminine Other: Masculinity, Femininity, and Gender Hegemony," Springer, vol. 36, no. 1, pp. 85102, 2007, doi: $10.1007 / \mathrm{s}$.

[9] W. L. Neuman, Social Research Methods: Quantitative and Qualitative Approaches, vol. 57, no. 2. 2014.

[10] E. Babbie, The Basics of Social Research : Fourth Edition. California: Thomson Higher Education, 2008. 